\title{
Pengaruh Teknik Penyuluhan Terhadap Keikutsertaan Pemeriksaan IVA Pada WUS Di Kelurahan Dasan Agung Kota Mataram Nusa Tenggara Barat
}

\author{
Mutiara Rachmawati Suseno ${ }^{1(\mathrm{CA})}$, Rosita Wati $^{2}$, Yunita Marliana ${ }^{3}$ \\ ${ }^{1(\mathrm{CA})}$ Jurusan Kebidanan, Poltekkes Kemenkes Mataram; susenomutiara@ gmail.com (Corresponding \\ Author) \\ ${ }^{2,3}$ Jurusan Kebidanan, Poltekkes Kemenkes Mataram
}

Genesis Naskah: Diterima 06 Oktober 2019;

Disetujui 13 November 2019;

Publikasi 15 November 2019

\begin{abstract}
Background and purpose: nationally the implementation of early detection program with IVA examination method simultaneously in all regions in Indonesia conducted on 21 April 2015 with efforts to reduce the incidence of ca cervical in Indonesia. In Puskesmas Dasan Agung, IVA examination program started in 2016 with the lowest presentation among all health centers in Mataram city that is much as $(1,39 \%)$ with the number of WUS 4153 soul and who come check as many as 58 people. This study aims to determine the influence of extension techniques on the participation of IVA examination in WUS in Kelurahan Dasan Agung. Methods: This research uses Quasi Experiment research design. The population in this study were all women of childbearing age in Kelurahan Dasan Agung as many as 2462 peoples. Samples in research using purposive sampling technique counted 60 peoples. The analysis used chisquare test. Results: From 60 respondents, who participated in IVA examination in the intervention group with 17 lectures $(56,7 \%)$ interactive lecture and control group with lecture counseling technique as many as 4 people $(13,3 \%)$. Chi-square analysis results obtained there is influence of extension technique to IVA examination involvement with obtained value $p$ value $=0,001$ atau $p<\alpha=0,05$. Conclusion: extension techniques have an effect on the participation of IVA examination in WUS in Kelurahan Dasan Agung.
\end{abstract}

Keywords: counseling technique; IVA examination

\begin{abstract}
ABSTRAK
Latar Belakang dan tujuan: Secara nasional, pelaksanaan program deteksi dini dengan metode pemeriksaan IVA secara serentak di seluruh wilayah Indonesia dilakukan pada 21 April 2015 dengan upaya untuk menurunkan angka kejadian ca cerviks di Indonesia. Di Puskesmas Dasan agung program pemeriksaan IVA dimulai pada tahun 2016 dengan presentasi terendah diantara seluruh Puskesmas di Kota Mataram yaitu sebanyak (1,39\%) dengan jumlah WUS 4153 jiwa dan yang datang periksa sebanyak 58 orang. Penelitian ini bertujuan untuk mengetahui pengaruh teknik penyuluhan terhadap keikutsertaan pemeriksaan IVA pada WUS di Kelurahan Dasan Agung. Metode: Penelitian ini menggunakan rancangan penelitian Quasi Experiment. Populasi dalam penelitian ini adalah seluruh wanita usia subur di Kelurahan Dasan Agung sebanyak 2462 orang. Sampel dalam penelitian menggunakan teknik purposive sampling sebanyak 60 orang. Analisis menggunakan uji chi-square. Hasil: Dari 60 orang responden, yang ikut serta dalam pemeriksaan IVA pada kelompok intervensi dengan penyuluhan ceramah interaktif sebanyak 17 orang $(56,7 \%)$ dan pada kelompok control dengan teknik penyuluhan ceramah sebanyak 4 orang $(13,3 \%)$. Hasil analisis chi-square didapatkan ada pengaruh teknik penyuluhan terhadap keikutsertaan pemeriksaan IVA dengan diperoleh nilai $\mathrm{p}$ value $=0,001$ atau $\mathrm{p}<\alpha=0,05$. Simpulan: teknik penyuluhan berpengaruh terhadap keikutsertaan pemeriksaan IVA pada WUS di Kelurahan Dasan Agung.
\end{abstract}

Kata Kunci : teknik penyuluhan; pemeriksaan IVA 


\section{PENDAHULUAN}

Angka kejadian kanker leher rahim menurut penelitian World Health Organization (WHO) (2005) menyebutkan terdapat lebih dari 500.000 kasus baru dan 260.000 kasus kematian akibat kanker leher rahim, 90\% diantaranya terjadi di Negara berkembang. Angka insiden tertinggi di temukan di Negaranegara Amerika bagian tengah dan selatan, Afrika timur, Asia selatan, Asia tenggara dan Melanesia (Depkes RI, 2009). ${ }^{1}$

Menurut World Health Organization (WHO) (2007), diperkirakan lebih dari 500.000 kasus baru kanker leher rahim ditemukan di dunia dan 90\% dari seluruh kasus tersebut terdapat di negara-negara berkembang. Hampir 260.000 kasus kematian wanita terjadi akibat kanker leher rahim dan hampir 95\% dari kasus tersebut terjadi di negara-negara berkembang. Bila hal ini tidak ditindak lanjuti dengan segera, kematian akibat kanker leher rahim diperkirakan akan meningkat hampir $25 \%$ pada sepuluh tahun mendatang (Depkes RI, 2009). ${ }^{1}$

Tingginya angka morbiditas dan mortalitas kanker serviks terjadi karena lebih dari $70 \%$ penderita datang dalam stadium lanjut, hal ini disebabkan karena pada stadium nol, satu dan dua kanker serviks tidak memperlihatkan adanya gejala, kurangnya pengetahuan serta minimnya informasi yang diperoleh mengenai penyakit kanker serviks, dan rendahnya cakupan deteksi dini (screening) (Nfa, 2008), hanya $5 \%$ perempuan di Negara berkembang yang mendapat pelayanan penapisan dibandingkan dengan $4 \%$ di Negara maju (Depkes RI, 2009). ${ }^{1}$

Program pemeriksaan atau skrinning dianjurkan dilakukan pada setiap perempuan satu kali pada usia 35-55 tahun dan idealnya dilakukan tiap 3 tahun pada wanita usia 25-60 tahun (Depkes RI, 2009). ${ }^{1}$

Berdasarkan hasil studi pendahuluan yang dilakukan peneliti di Puskesmas Dasan Agung, peneliti menemukan dari 3 WUS yang datang pasang KB di Ruang Poli KIA, didapatkan ketiga WUS tersebut belum pernah mendengar mengenai pemeriksaan IVA sehingga belum pernah periksa IVA sama sekali, setelah penyuluhan dengan teknik ceramah dengan menggunakan media leaflet dilakukan, ketiga WUS tahu dan mengerti tentang deteksi dini kanker serviks dengan pemeriksaan IVA dan berencana untuk periksa IVA setelah memberitahukan suami. Sehingga, berdasarkan uraian latar belakang tersebut, perlu adanya suatu tentang "pengaruh teknik penyuluhan terhadap keikutsertaan pemeriksaan IVA pada WUS di Kelurahan Dasan Agung Tahun 2017."

\section{METODE}

Penelitian ini menggunakan jenis rancangan penelitian Quasi Experiment yaitu percobaan yang bertujuan untuk mengetahui suatu gejala atau pengaruh yang ditimbulkan (keikutsertaan melakukan pemeriksaan IVA secara mandiri), sebagai akibat adanya intervensi atau perlakuan tertentu (penyuluhan tentang kanker serviks).

Kasus adalah WUS yang diberikan penyuluhan dengan teknik interaktif sebanyak dua kali pertemuan. Pada penyuluhan pertama, dilakukan evaluasi lansung untuk WUS yang bersedia melakukan pemeriksaan IVA, kemudian WUS yang belum bersedia melakukan pemeriksaan IVA dijadwalkan kembali untuk diberikan penyuluhan kedua pada posyandu berikutnya. Sedangkan kontrol adalah WUS yang diberikan penyuluhan dengan teknik ceramah sebanyak satu kali kemudian evaluasi dilakukan 
selama dua minggu untuk melihat berapa banyak WUS yang bersedia untuk melakukan pemeriksaan IVA. Sumber kasus dan kontrol adalah dari register KIA Puskesmas Dasan Agung tahun 2017. Besar sampel yang digunakan adalah sampel minimal yaitu sebanyak 30 responden. Teknik pengambilan sampel kasus dan kontrol menggunakan purposive sampling. Peneliti menggunakan tingkat kemaknaan $\mathrm{p}=0,05$ dan confidence interval $(95 \%)$.

Variabel terikat dalam penelitian ini adalah keikutsertaan untuk pemeriksaan IVA. Selain itu dikumpulkan pula variabel tentang karakteristik ibu (usia, pendidikan, pekerjaan, dan riwayat kanker keluarga). Analisis univariat bertujuan untuk mendeskripsikan karakteristik dari masing-masing variabel yang diteliti. Sedangkan, analisis bivariat bertujuan untuk menguji perbedaan dan menguji hubungan antar dua variabel penelitian (kasus dan kontrol).

\section{HASIL}

Pada Tabel 1 berikut disajikan gambaran karakteristik responden di Kelurahan Dasan Agung berdasarkan usia, pendidikan, pekerjaan dan riwayat kanker keluarga.

Tabel 1. Karakteristik responden

\begin{tabular}{|c|c|c|c|c|c|c|c|}
\hline \multirow[t]{2}{*}{ Karakteristik } & \multicolumn{2}{|c|}{ lntervensi } & \multicolumn{2}{|c|}{ Control } & \multirow{2}{*}{$\begin{array}{l}\text { Ikut } \\
\text { periksa } \\
\text { IVA }\end{array}$} & \multirow[t]{2}{*}{ sumlah } & \multirow[t]{2}{*}{ Presentase } \\
\hline & & $\%$ & $\mathrm{n}$ & $\%$ & & & \\
\hline $\begin{array}{l}\text { Umur } \\
<30 \text { tahun } \\
>30 \text { tahun }\end{array}$ & $\begin{array}{l}14 \\
16\end{array}$ & $\begin{array}{l}46,7 \% \\
53,3 \%\end{array}$ & $\begin{array}{l}12 \\
18\end{array}$ & $\begin{array}{l}40 \% \\
60 \%\end{array}$ & $\begin{array}{c}8 \\
13\end{array}$ & $\begin{array}{l}26 \\
34\end{array}$ & $\begin{array}{l}43,3 \% \\
56,7 \%\end{array}$ \\
\hline $\begin{array}{l}\text { Pendidikan } \\
\text { Rendah } \\
\text { Menengah } \\
\text { Tingai }\end{array}$ & $\begin{array}{c}8 \\
22 \\
0\end{array}$ & $\begin{array}{c}26,7 \% \\
73,3 \% \\
0 \%\end{array}$ & $\begin{array}{c}9 \\
19 \\
2\end{array}$ & $\begin{array}{l}30 \% \\
63,3 \% \\
6,7 \%\end{array}$ & $\begin{array}{c}9 \\
12 \\
0\end{array}$ & $\begin{array}{c}17 \\
41 \\
2\end{array}$ & $\begin{array}{c}28,4 \% \\
68,3 \% \\
3,3 \%\end{array}$ \\
\hline $\begin{array}{l}\text { Pekerjaan } \\
\text { IRT } \\
\text { Wiraswasta } \\
\text { Swasta } \\
\text { PNS/honorer }\end{array}$ & $\begin{array}{c}21 \\
8 \\
1 \\
0\end{array}$ & $\begin{array}{l}70 \% \\
26,7 \% \\
3,3 \% \\
0 \%\end{array}$ & $\begin{array}{c}25 \\
3 \\
1 \\
1\end{array}$ & $\begin{array}{l}83,4 \% \\
10 \% \\
3,3 \% \\
3,3 \%\end{array}$ & $\begin{array}{l}17 \\
4 \\
0 \\
0\end{array}$ & $\begin{array}{c}46 \\
11 \\
2 \\
1\end{array}$ & $\begin{array}{c}76,7 \% \\
18,3 \% \\
3,3 \% \\
1,7 \%\end{array}$ \\
\hline \multicolumn{8}{|c|}{ Riwayat Kanker Keluarga } \\
\hline $\begin{array}{l}\text { Ada } \\
\text { Tidak ada }\end{array}$ & $\begin{array}{c}0 \\
30\end{array}$ & $\begin{array}{c}0 \% \\
100 \%\end{array}$ & $\begin{array}{r}2 \\
28\end{array}$ & $\begin{array}{l}6,7 \% \\
93,3 \%\end{array}$ & $\begin{array}{c}0 \\
21\end{array}$ & $\begin{array}{c}2 \\
58\end{array}$ & $\begin{array}{l}3,3 \% \\
96,7 \%\end{array}$ \\
\hline
\end{tabular}

Berdasarkan Tabel 1 tersebut, menunjukkan bahwa distribusi responden berdasarkan umur mayoritas berusia lebih dari 30 tahun yaitu sebanyak 34 responden (56,7\%), responden terbanyak berpendidikan menengah sejumlah 41 respondenv(68,3\%), sebagian besar responden bekerja sebagai ibu rumah tangga yaitu sejumlah 46 responden $(76,7 \%)$, dan sebagian besar tidak memiliki riwayat kanker keluarga yaitu sejumlah 58 responden $(96,7 \%)$.

Tabel 2. Keikutsertaan WUS dalam pemeriksaan IVA

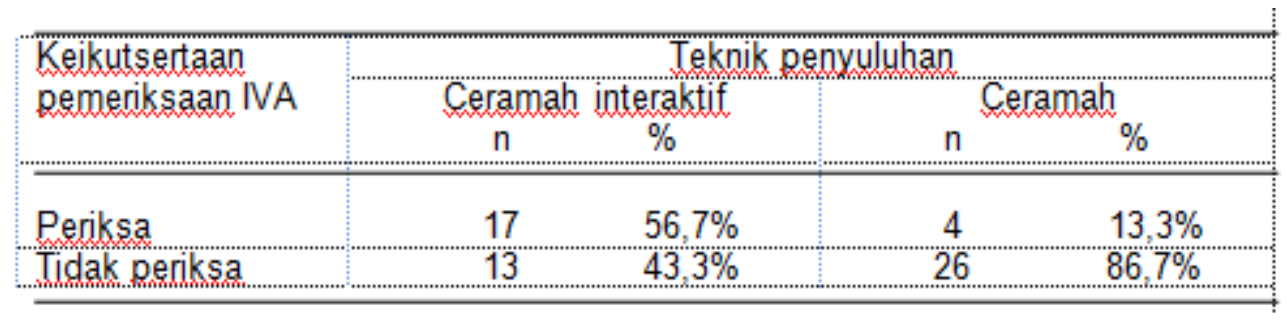


Pada Tabel 2 dapat dilihat bahwa sebagian besar yang ikut serta dalam pemeriksaan IVA yaitu pada kelompok intervensi dengan teknik penyuluhan interaktif yaitu sebanyak 17 responden $(56,7 \%)$, sedangkan pada kelompok control dengan teknik ceramah sebanyak 4 responden $(13,3 \%)$.

Tabel 3. Analisis bivariat pengaruh teknik penyuluhan terhadap keikutsertaan pemeriksaan IVA pada WUS di Kelurahan Dasan Agung tahun 2017

\begin{tabular}{|c|c|c|c|c|}
\hline \multirow{2}{*}{$\begin{array}{l}\text { Keikutsertaan } \\
\text { pemeriksaan } \\
\text { IVA }\end{array}$} & \multicolumn{3}{|c|}{ Teknik penyuluhhn } & \multirow[t]{2}{*}{ P. Value } \\
\hline & 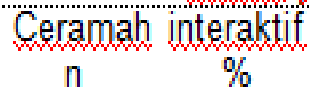 & & $\%$ & \\
\hline Periksa & $56,7 \%$ & 4 & $13,3 \%$ & 0,001 \\
\hline Tidak periksa & $43,3 \%$ & 26 & $86,7 \%$ & \\
\hline
\end{tabular}

Pada Tabel 3 disajikan hasil analisis bivariat dengan chi-square dua sampel untuk mengetahui pengaruh teknik penyuluhan terhadap keikutsertaan WUS dalam pemeriksaan IVA. Hasil uji tersebut menunjukkan 0,001 ( $p$ value< 0,05). Hal ini membuktikan bahwa terdapat pengaruh yang signifikan teknik penyuluhan yang diberikan terhadap keikutsertaan WUS dalam pemeriksaan IVA di Kelurahan Dasan Agung Tahun 2017.

\section{PEMBAHASAN}

Dalam penelitian ini terbukti bahwa teknik penyuluhan mempengaruhi keikutsertaan WUS dalam pemeriksaan IVA dengan $p$ value 0,001 < 0,05. Karakteristik WUS jika dilihat dari faktor usia, pendidikan, pekerjaan dan riwayat kanker keluarga memiliki pengaruh terhadap keikutsertaan dalam pemeriksaan IVA.

Menurut teori dalam Depkes RI tahun (2009) yang menyebutkan bahwa pemeriksaan deteksi dini kanker leher rahim di Indonesia dianjurkan bagi semua perempuan berumur 30 sampai 50 tahun. Kasus kejadian kanker leher rahim paling tinggi terjadi pada umur 40 dan 50 tahun, sehingga tes harus dilakukan pada umur dimana lesi pra kanker lebih mungkin terdeteksi, yaitu biasanya 10 sampai 20 tahun lebih awal. ${ }^{1}$

Prawihardjo (2005) dalam penelitian Irma Wulandari Ni Luh Putu menyatakan ibu yang berusia sekitar 30 sampai 40 tahun memiliki tingkat kewaspadaan yang lebih tinggi untuk mencegah terjadinya kanker serviks. Semakin dini WUS memeriksakan diri maka secara dini akan diketahui adanya kanker serviks. $^{2}$

Faktor selain usia adalah tingkat pendidikan. Tingkat pendidikan sangat berpengaruh terhadap pengetahuan ibu dalam pembentuk perilaku seseorang. Semakin tinggi tingkat pendidikan seseorang, semakin mudah menerima informasi sehingga semakin banyak pula menerima pengetahuan yang dimilikinya dan jika tingkat pendidikan rendah, maka akan menghambat perkembangan perilaku seseorang terhadap penerimaan, informasi, dan nilai-nilai yang baru diperkenalkan. ${ }^{2}$

Selain itu, pekerjaan juga mempengaruhi keikutsertaan WUS dalam pemeriksaan IVA. pekerjaan akan mempengaruhi tingkat ekonomi seseorang. Tingkat sosial ekonomi yang terlalu rendah akan 
mempengaruhi individu menjadi tidak begitu memperhatikan pesan-pesan yang disampaikan karena lebih memikirkan kebutuhan-kebutuhan lain yang lebih mendesak. ${ }^{2}$

Hal ini sesuai dengan penelitian Melva (2008) menyebutkan bahwa kanker leher rahim berhubungan dengan pekerjaan, dimana bila dibandingkan dengan wanita pekerja ringan atau pekerja di kantor (sosial ekonomi menengah ke atas), wanita pekerja kasar, seperti buruh dan petani (sosial ekonomi rendah), mempunyai resiko 4 kali lebih tinggi. ${ }^{3}$

Sedangkan, faktor yang terakhir yang mempengaruhi keikutsertaan WUS dalam pemeriksaan IVA adalah riwayat kanker keluarga. Susanto (2008) menyebutkan keluarga adalah kumpulan beberapa orang yang karena terikat oleh satu turunan lalu mengerti dan merasa berdiri sebagai satu gabungan yang hakiki, esensial, enak dan berkehendak bersama-sama memperteguh gabungan itu untuk memuliakan masingmasing anggotanya. ${ }^{2} \mathrm{Hal}$ ini diperkuat dengan hasil penelitian Trisi I ia, Riesa (2009) di Puskesmas AlunAlun Kabupaten Gresik menunjukkan bahwa karakteristik responden (tingkat pengetahuan, usia, pekerjaan, faktor atau riwayat kanker) tidak berpengaruh signifikan terhadap keikutsertaan wanita dalam pemeriksaan IVA. ${ }^{5}$

\section{KESIMPULAN}

Keikutsertaan WUS dalam pemeriksaan IVA dapat dipengaruhi oleh beberapa faktor, yaitu usia, pendidikan, pekerjaan dan riwayat kanker keluarga. Oleh karena itu, teknik penyuluhan terbukti dapat mempengaruhi keikutsertaan WUS dalam emeriksaan IVA. Teknik penyuluhan dengan ceramah interaktif dapat dijadikan sebagai salah satu cara untuk menarik minat WUS dalam pemeriksaan IVA sehingga skrining tentang kanker serviks dapat dilakukan lebih awal yang dapat menurunkan angka kejadian kanker serviks pada wanita usia subur.

\section{DAFTAR PUSTAKA}

Azhar Arysad, 2006. Media Pengajaran, Jakarta: Raja Grafindo

Departemen Kesehatan Republik Indonesia, 2009. Buku Acuan Pencegahan Kanker Leher Rahim dan Kanker Payudara. Jakarta: DepKes RI.

Dinas Kesehatan, Kota Mataram, 2014. Profil kesehatan Kota Mataram 2014

Dwi Setiyono Bambang, 2008. Pengembangan Pembelajaran Dengan Menggunakan Multimedia Interaktif Untuk Pembelajaran Yang Berkualitas, Semarang: UNNES

Emilia Oka, (k), dkk, 2010. Bebas Ancaman Kanker Serviks. Yogyakarta: Med Press

Irma Wulandari Ni Luh Putu, 2017. Faktor-Faktor Yang Berhubungan Dengan Pemeriksaan IVA Pada Wanita Pekerja Seksual Di Lokalisasi Sunan Kuning Wilayah Kerja Puskesmas Lebdosari. Semarang: Fakultas Keperawatan Universitas Ngudi Waluyo Ungaran

Kholid Ahmad, 2012. Promosi Kesehatan Dengan Pendekatan Teori Perilaku, Media Dan Aplikasinya. Jakarta: PT Raja Grafinfo Persada 
Lubis ZSA, Lubis NL, Syahrial E, 2013. Pengaruh Penyuluhan Dengan Metode Ceramah Dan Diskusi Terhadap Peningkatan Pengetahuan Dan Sikap Anak Tentang PHBS Di Sekolah Dasar Negeri 065014 Kelurahan Namogajah Kecamatan Medan Tuntungan. Sumatera: Universitas Sumatera Utara

Lucie S, 2005. Tekhnik Penyuluhan Dan Pemberdayaan Masyarakat. Bogor: Ghalia Indonesia

Melva, 2008. Factor-faktor yang mempengaruhi kejadian kanker leher rahim pada penederita yang datang berobat di RSUP H.Adam Malik. Medan: Universitas Sumatera Utara

Rahmawati Ira, dkk, 2007. Pengaruh Penyuluhan Dengan Media Audio Visual Terhadap Peningkatan Pengetahuan, Sikap Dan Perilaku Ibu Balita Gizi Kurang Dan Buruk Di Kabupaten Kotawaringin Barat Kalimantan Tengah

Rini, Lestari M, 2009. Analisis Faktor-Faktor Yang Mempengaruhi Temuan IVA Positif Di Puskesmas Jatinegara. Jakarta: Skripsi FKUI

Rohani, Fitri, 2009. Factor Factor Yang Mempengaruhi Kejadian Kanker Serviks Di Puskesmas Karang Anyar. Gombong: Skripsi Stikes Muhammadiyah Gombong

Sari Dewi Adinda Putri, 2013. Pengaruh Penyuluhan Kanker Serviks Terhadap Sikap Pemeriksaan IVA Pada WUS

Setiawan Dalimartha, 2004. Deteksi Dini Kanker Serviks Dengan IVA. Jakarta: Penebar Swadaya

Sridewi Ni Made, dkk, 2013. Hubungan Pengetahuan Dan Sikap WUS Dengan Pemeriksaan IVA di Puskesmas Beleleng, Bali

Sudjanadan Nana, Rivai Ahmad, 2003. Teknologi Pengajaran. Bandung: Sinar Baru Algesindo

Sugiyono, 2014. Metode Penelitian Kuantitatif, Kualitatif dan R\&D. Bandung: Alfabeta

Suprijono, 2008. Inspeksi Visual Asam Asetat (IVA) Untuk Deteksi Dini Lesi Pra Kanker Serviks. Semarang: Skripsi Fakultas Kedokteran Universitas Diponegoro

Syafrudin, dkk, 2011. Himpunan Penyuluhan Kesehatan. Jakarta: Trans Indo Media

Taringan Aps, 2010. Efektifitas Metode Ceramah Dan Diskusi Kelompok Terhadap Pengetahuan dan Sikap tentang Kesehatan Reproduksi pada Remaja di Yayasan Pendidikan Harapan Mekar Medan. Sumatera: Universitas Sumatera Utara

Trisi I ia, Riesa, 2009. Analisis Keikutsertaan Wanita Dalam Pemeriksaan Inspeksi Visual Dengan Asam Asetat (IVA) Sebagai Metode Skrining Alternative Kanker Serviks Di Pueskesmas Alun-Alun Kabupaten Gresik. Tesis UNAIR

Wijayati Wahyu, 2014. Perbedaan Peningkatan Pengetahuan Dan Sikap Kader Posyandu Tentang Pelaksanaan Relaktasi Pasca Penyuluhan Antara Menggunakan Metode Diskusi Kelompok Dan Ceramah Interaktif. Kediri: Prodi DIII Kebidanan STIKES Karya Husada Kediri

Waluyaningsih Sri, 2013. Pengaruh Penyuluhan Kanker Serviks Terhadap Keikutsertaan Pemeriksaan IVA Pada Ibu Usia 30-50 Tahun

Wijaya Delia, 2010. Pembunuh Ganas Itu Bernama Kanker Serviks. Yogyakarta: Sinar Kejora 